\title{
MANAGEMENT OF NATIVE SOIL NITROGEN FOR REDUCING NITROUS OXIDE EMSSIONS AND HIGHER RICE PRODUCTION
}

\author{
Keshav R. Pandey $(\mathrm{PhD})^{1}$, S.C.Shah $(\mathrm{PhD})^{2}$ and $\mathrm{M}$. Becker $(\mathrm{PhD})^{3}$
}

\begin{abstract}
Present production of rice is far below its reported potential yield because of being $\mathrm{N}$ deficiency, the major constraint. Because of poverty, small farmers have to rely on native soil N-supply. Between wheat harvest and rice transplanting, a dry-to-wet season transition (DWT) period exist with changing soil moisture from aerobic to anaerobic and a large amount of native soil $\mathrm{N}$ loss is hypothesized. To study soil $\mathrm{N}$ dynamism and possible management options for DWT, two years field experiments were conducted in Chitwan with four land management treatments like bare fallow, mucuna, mungbean and maize. Treatments were randomly allotted in $10 \mathrm{~m}^{2}$ plots. During DWT, building up of $50-75 \mathrm{~kg}$ of nitrate- $\mathrm{N}$ was observed at 60-75\% field capacity (FC) soil moisture but lost after flooding through leaching and denitrification, resulting in low grain yield and $\mathrm{N}$ uptake of succeeding rice. Growing cover crops during DWT, reduced leaching loss by half and $\mathrm{N}_{2} \mathrm{O}$ emissions by two thirds of those in the bare fallows. Atmospheric- $N$ addition by legumes ranged from 27 to $56 \mathrm{~kg} \mathrm{ha}^{-1}$ depending on the types of legumes and increased $\mathrm{N}$ uptake and grain yield by $24-42 \mathrm{~kg} \mathrm{~N} \mathrm{ha-1}$ $\mathrm{yr}^{-1}$ and $1.2-2.1 \mathrm{Mg} \mathrm{ha}^{-1} \mathrm{yr}^{-1}$ respectively. Thus, cultivation of grain/green manure legumes appears economically and ecologically beneficial.
\end{abstract}

Key Words: bare fallow, crop $\mathrm{N}$ uptake, denitrification, green manure, leaching, nitrate catch crops, nitrification

\section{INTRODUCTION}

Rice (Oryza sativa L.) is an important food crop of Nepal. Rice and wheat provide food for about 23 million people in Nepal (Ladha et al., 2000) and cover about 0.5 million hectares in Nepal (Hobbs and Morris, 1996). The reported maximum grain yield of rice was $8 \mathrm{Mg} \mathrm{ha}^{-1}$ in mid hills research station at Khumaltar (Pandey et al., 1999) and $5 \mathrm{Mg} \mathrm{ha}^{-1}$ in an experimental station at Bhairahawa (Regmi et al., 2002). Long-term monitoring on experimental stations and farmers' field indicates that at constant inputs, the grain yield of both crops is declining. Currently, the mean yield of rice is $2 \mathrm{Mg} \mathrm{ha}^{-1}$ (Pandey et al., 1999). However, to provide food for a rapidly growing population, Nepal needs to increase the production of rice by $1 \mathrm{Mg} \mathrm{ha}{ }^{-1}$ and that of wheat by $0.6 \mathrm{Mg} \mathrm{ha}^{-1}$ by the end of 2020 (Hobbs and Adhikari, 1997; Gami et al., 2001). The gap between the maximum observed and national average yield as well as the declining yield trend requires an urgent research attention.

A number of factors have been associated with the current low and even declining productivity of the system. A diagnostic field survey conducted in the Terai area of Nepal identified both short-term and long-term key problems associated with low production and declining productivity in the rice-wheat system (Harrington et al., 1993). Dominating both the long and short-term problems are soil fertility issues, primarily associated with $\mathrm{N}$ deficiency.

\footnotetext{
${ }^{1}$ Institute of Agriculture and Animal Science, T. U., Nepal, Email: keshabrajpande@yahoo.com

2 Prof. Institute of Agriculture and Animal Sciences, T.U.

3 Prof. University of Bonn, Germany
} 
Since about $40 \%$ of Nepalese farmers live below the poverty line with less than 244 US\$ per capita of annual income (CBS, 2001), the use of external inputs (i.e. mineral fertilizers) are not affordable to these marginal farmers. Because of poor road networking, the availability of mineral fertilizers is not on time. Consequently, the $\mathrm{N}$ nutrition of rice largely based on the supply from the native soil $\mathrm{N}$ pool and animal manure. Under such circumstances, the efficient use of systems' internal resources such as the recycling of crop residues and manures, minimization of nutrient losses, and the addition of $\mathrm{N}$ by biologically fixed $\mathrm{N}$ (BNF) must be explored to much larger extent than at present.

\section{OBJ ECTIVES}

Two years field experiments were conducted in Agronomy farm of Rampur Campus and participatory research in three field sites of Chitwan. The objectives of the study were to

(1) quantify the effect of DWT land management on

soil $\mathrm{N}$ mineralization, nitrate- $\mathrm{N}$ leaching and $\mathrm{N}_{2} \mathrm{O}$ emissions

$\mathrm{N}$ immobilization in grown crop biomass

atmospheric $\mathrm{N}_{2}$ fixation by legumes

(2) evaluate the effect of DWT land management on wet season rice, involving soil and residue $\mathrm{N}$ mineralization

grain yield and $\mathrm{N}$ uptake

\section{MATERIALS AND METHODS}

Two years field trials were conducted in agronomy farm of Rampur Campus and in three farmers' fields of Mangalpur Village Development Committee, Chitwan. The experimental sites were located at $27^{\circ} 37^{\prime} \mathrm{N}$ latitude and $84^{\circ} 25^{\prime} \mathrm{E}$ longitude with an elevation of $240-260$ meter above sea level. The monthly rainfall gradually increased from $101 \mathrm{~mm}$ in April to 930

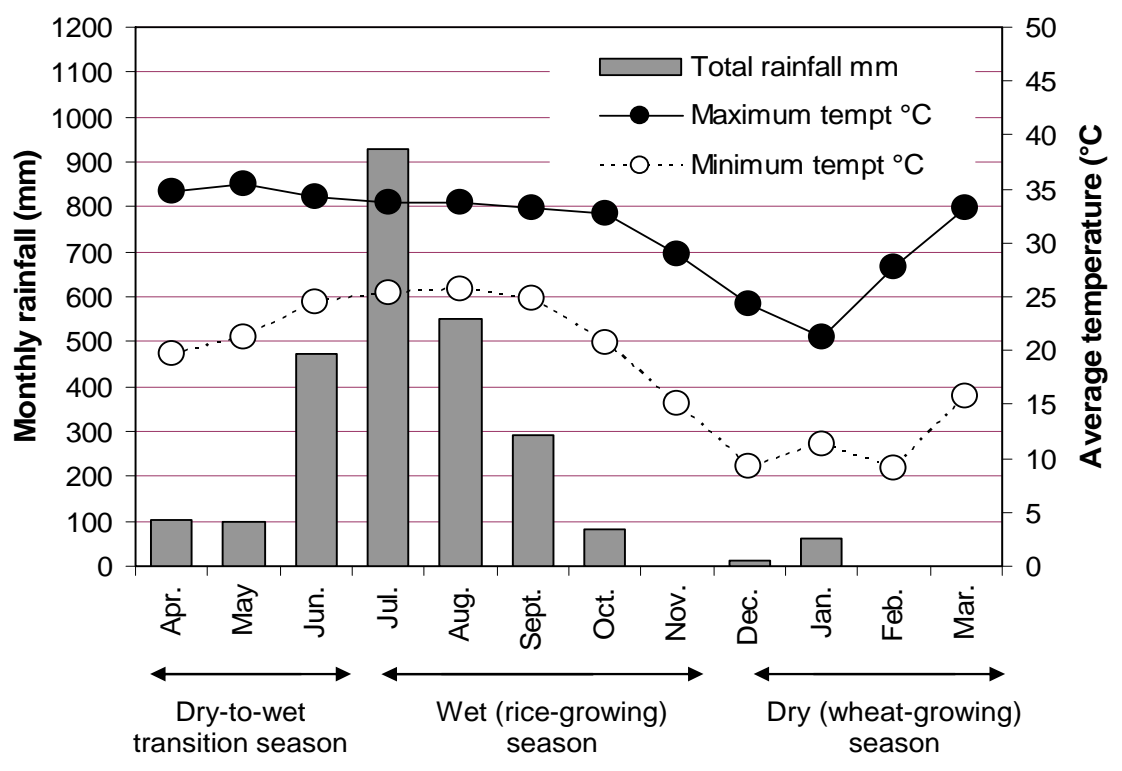
$\mathrm{mm}$ in July. The total annual rainfall of 2600 $\mathrm{mm}$ is concentrated in the period between May and October. The site was under continuous rice-wheat rotation for more than 10 years. The transplanting period is June-July and before transplanting of lowland rice there exists a DWT period. The average monthly temperatures and rainfall of the experimental site are presented below.

Figure 1. Monthly rainfall and mean maximum-minimum temperatures at the lowland field site in Nepal (field experiment, Rampur, Chitwan province, Nepal, 2003). 


\section{Eexperimental soils}

Soils at the experimental field sites were sandy loam. The soil reaction is acidic $(\mathrm{pH}$ 6.1-6.8) with low organic carbon (1.1-1.5\%) and low nitrogen $(0.1 \%)$.

\section{Plant material}

Freshly uprooted, 21-day-old seedlings of Masuli rice were transplanted at $20 \times 20 \mathrm{~cm}$ spacing with three seedlings per hill in the puddled, flooded soil during wet season. Mucuna (puriens var utilis L.), mungbean (Vigna radiata L.) and maize (Zea mays) were DWT period landmanagement crops. Mucuna, mung bean and maize were seeded at $40 \times 30 \mathrm{~cm}, 40 \times 5 \mathrm{~cm}$ and $40 \times 20 \mathrm{~cm}$ spacing respectively.

Soil and plant analyses

The crop dry matter was determined based on $1 \mathrm{~m}^{2}$ harvest areas at the end of DWT. The total $\mathrm{N}$ was determined by micro-Kjeldahl and ${ }^{15} \mathrm{~N}$ was analysed using mass spectrometry (ANCA SL coupled to 20-20 stable isotope analyser IRMS, Europa scientific/ PDZ now Sercon Ltd., UK). The natural abundance of the staple isotope ${ }^{15} \mathrm{~N}$ was determined in finly ground plant samples using the method described by Shearer and Kohl (1980) with

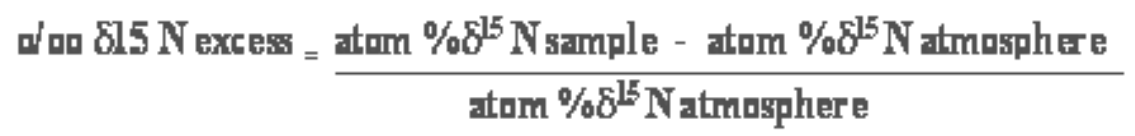

The share of biological nitrogen fixation was calculated as,

$$
\mathrm{Ndfa} \%=1-\frac{\delta^{15} \mathrm{~N} \text { excess in the sample }}{\delta^{15} \mathrm{~N} \text { excess in the reference plant }+\beta} \times 100
$$

The $\mathrm{B}$-values for natural discrimination against ${ }^{15} \mathrm{~N}$ were taken from Becker and Johnson (1998). Soil samples of about $40 \mathrm{~g}$ (dry weight) were extracted with $100 \mathrm{ml}$ of $2 \mathrm{M} \mathrm{KCl}$ after shaking for two hours. Ammonium and nitrate nitrogen were determined colorimetrically using an EC standard Autoanalyser III, Bran+Luebbe, Norderstedt, Germany.

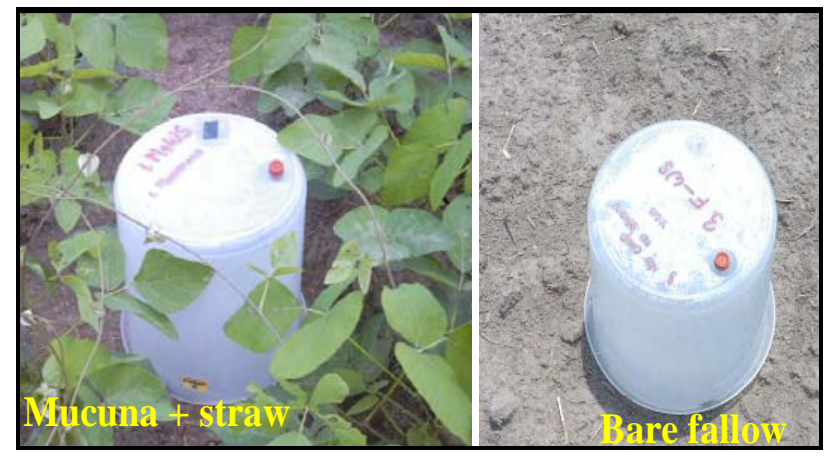

(a)

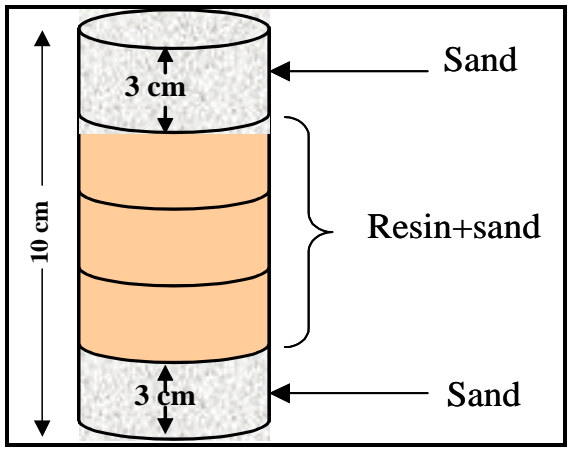

(b)

Figure 2. $\mathrm{NO}_{3}-\mathrm{N}$ collection chambers in the field plots (a) and resin capsule (b) prepared to put in the soil to measure nitrate leaching, Rampur, Chitwan, Nepal, 2003. 
The $\mathrm{NO}_{3}-\mathrm{N}$ leached from the topsoil during DWT was determined in mixed ion-exchange resin cores containing three resin bags in each core and placed at $30 \mathrm{~cm}$ depth. Nitrous oxide emission from soils during the DWT was collected bi-weekly in closed chambers of $19 \mathrm{~cm}$ diameter and $24 \mathrm{~cm}$ height as well as after each rainfall in $20 \mathrm{ml}$ closed vials by double displacement method. The initial gas sample was taken just after installation of the chamber and next after 2 hours later. Gas samples were analyzed for $\mathrm{N}_{2} \mathrm{O}$ by using gas chromatography (SRI [Torrance, CA] 8610C) with a back flush system to eliminate water vapour and on an electron capture detector (ECD) at a column temperature of $40^{\circ} \mathrm{C}$, and $E C D$ temperature of $320^{\circ} \mathrm{C}$. The $\mathrm{N}_{2} \mathrm{O}$ emission was expressed as $\mu \mathrm{g} \mathrm{m}^{-2} \mathrm{~h}^{-1}$. The soil moisture was measured biweekly at a depth of $10 \mathrm{~cm}$ during DWT by using Time Domain Refractometer (TDR: Trime FM 2 (IMCO GmbH, Ettlingen, Germany).

\section{Treatments application}

The DWT period land management treatments were bare fallow and three different transition season crops, namely mucuna, mungbean and maize. Treatments were arranged in a Complete Randomized Block Design (RCBD) in four times replicated 4mx3m sized plots.

\section{RESULTS AND DISCUSSION}

The outcomes of the experiments are presented and discussed with findings of the other workers in this section.

\section{Soil N dynamics during the dry-to-wet transition season}

The DWT period in rice-wheat fields of the Terai, Inner-Terai, river basins (tars) were long enough to grow transition season crops to manage seasonal soil $\mathrm{N}$ dynamics. A gradual increment in soil moisture resulted change in the available forms of $\mathrm{N}_{\min }$ in the soil. The initial $\mathrm{NH}_{4}-\mathrm{N}$ content in the bare soil decreased from 21.2 to $5.9 \mathrm{~kg} \mathrm{ha}^{-1}$ and from 12.3 to $9.3 \mathrm{~kg} \mathrm{ha}-1$ at 6 weeks after wheat harvesting in the years 2001 and 2003, respectively. At soil saturation by the monsoon rains, the $\mathrm{NH}_{4}-\mathrm{N}$ content gradually increased to 26.4 and $28.8 \mathrm{~kg} \mathrm{ha}^{-1}$ after 14 weeks of wheat harvesting in the years 2001 and 2003, respectively. A reverse pattern was observed in the case of $\mathrm{NO}_{3}-\mathrm{N}$ in both years. Nitrate peak of $51 \mathrm{~kg} \mathrm{ha}^{-1}$ and $75.3 \mathrm{~kg} \mathrm{ha}^{-1}$ were observed in the bare fallow soil in the years 2001 and 2003, respectively. With the onset of monsoon rain, the bare soil was saturated by water and almost all $\mathrm{NO}_{3}-\mathrm{N}$ disappeared from the soil in both years.

The highest $\mathrm{NO}_{3}-\mathrm{N}\left(51 \mathrm{~kg} \mathrm{ha}^{-1}\right.$ in 2001 and $75 \mathrm{~kg} \mathrm{ha}^{-1}$ in 2003) built up was observed at soil moisture content of $60-75 \%$ FC under bare fallow. Other workers like Inubushi et al. (1996) observed a nitrate peak at 60\% FC and Flessa et al. (1996), Bollmann and Conrad (1998) observed nitrate peak at $<80 \%$ FC. Thus, in present study $60-75 \%$ FC soil moisture was most favourable for nitrifying bacteria and that result the highest $\mathrm{NO}_{3}-\mathrm{N}$ in the soil. However, the $\mathrm{NO}_{3}-\mathrm{N}$ peak observed in 2003 was much higher than that in 2001. In 2003, the soil drying and wetting cycles were more frequent and more severe than in 2001. As Sehy, et al. (2004) observed an enhanced activity of nitrifying bacteria in the soil under frequent soil drying and wetting, the higher nitrate peak in 2003 could be due to the presence of higher frequency of wetting and drying cycles.

Numbers of studies on the $\mathrm{N}$ dynamics in seasonally flooded soils of South Asia, and Southeast Asia highlighted the occurrence of the Birch effect ( $\mathrm{N}$ mineralization peak) after the first 
rains and the near complete disappearance of the nitrate fraction at the beginning of the main wet season (Pande and Becker, 2003; Shrestha and Ladha, 1998). Numerous authors reported large $\mathrm{N}$ losses by denitrification after soil flooding (Bacon et al., 1986). In present study, the disappearance of 47-73 $\mathrm{kg} \mathrm{NO}_{3}-\mathrm{N} \mathrm{ha}^{-1}$ from the field at the end of DWT may be attributed to a combination of nitrate leaching and denitrification caused by heavy rain and soil saturation.
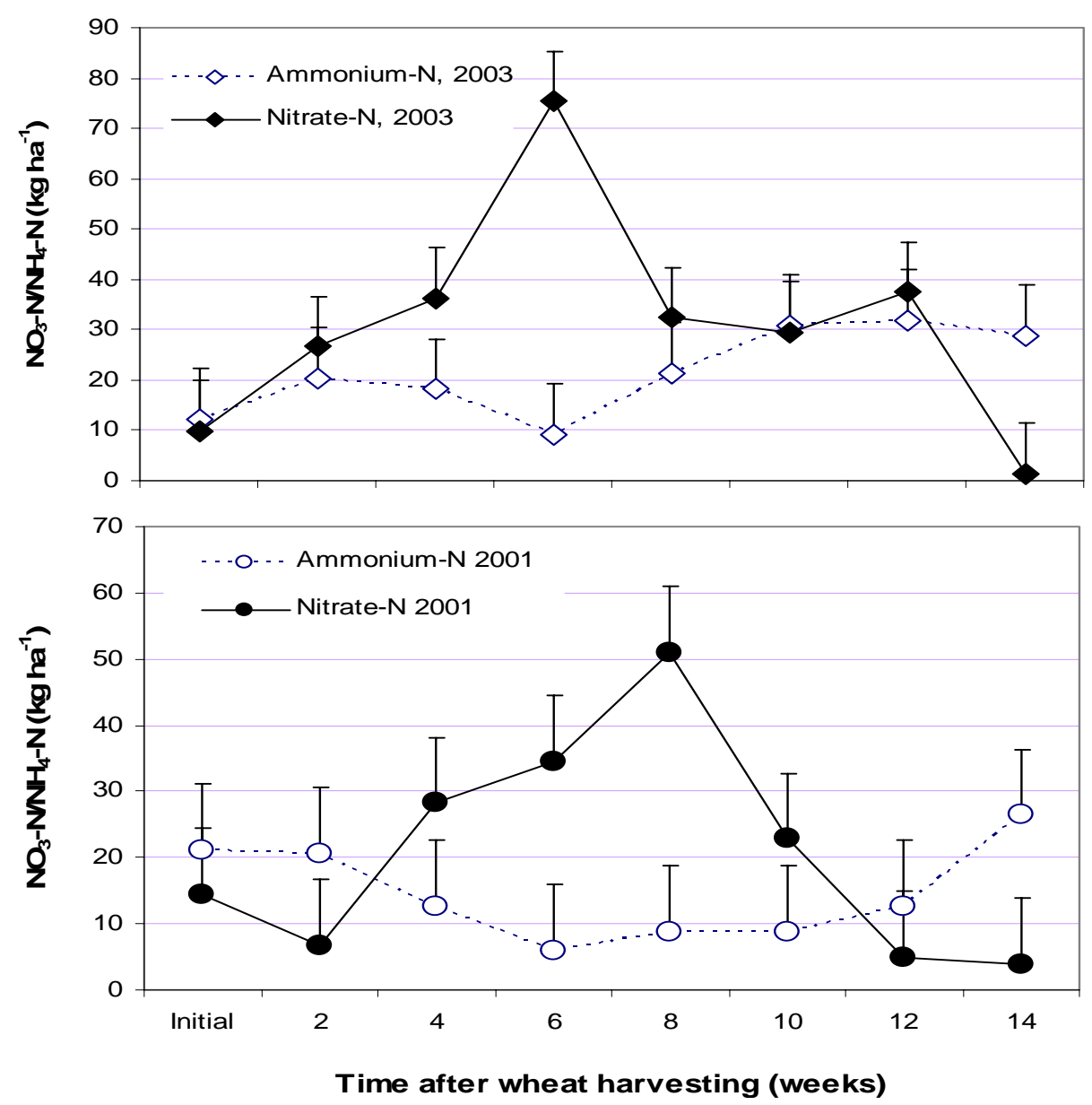

Figure 3. Soil $\mathrm{N}_{\min }$ dynamics in the bare fallow soil during the dry-to-wet season transition period (2001 and 2003). Bars present standard errors of the mean $(n=4)$.

The growth of the transition season crops reduced the soil $\mathrm{NO}_{3}-\mathrm{N}$ peak from $51 \mathrm{~kg} \mathrm{ha}^{-1}$ in the bare fallow to 25,27 and $32 \mathrm{~kg} \mathrm{ha}^{-1}$ in 2001 and from $75 \mathrm{~kg} \mathrm{ha}^{-1}$ to $34.9,36.6$ and $29.4 \mathrm{~kg} \mathrm{ha}^{-1}$ in 2003 in the land management treatments maize, mungbean and mucuna respectively. Large differences in $\mathrm{NO}_{3}-\mathrm{N}$ leaching from the top soil were also observed among DWT treatments. The highest amount $\left(12 \mathrm{~kg} \mathrm{ha}^{-1}\right) \mathrm{NO}_{3}-\mathrm{N}$ leached from the topsoil from the bare fallow control and the lowest $0.57 \mathrm{~kg} \mathrm{ha}^{-1}$ of $\mathrm{NO}_{3}-\mathrm{N}$ was leached from the mucuna treatment. Other workers like Kladivko et al. (2004), also observed reduced nitrate leaching from a topsoil of Indiana by growing nitrate trap crops in the field. Shrestha and Ladha (1998), observed significantly $(\mathrm{P}=0.05)$ reduced $\mathrm{NO}_{3}-\mathrm{N}$ leaching from the plots with maize, indigo, and mungbean during DWT than bare fallow control in the Philippines. Hartemink et al. (1996) observed a significantly reduced $\mathrm{NO}_{3}-\mathrm{N}$ leaching from the topsoil in the Sesbania sesban, Zea 
mays and weedy fallow than bare fallow. Present study, the lowest $\mathrm{NO}_{3}-\mathrm{N}$ leached from the plots of mucuna treatment could be linked with immobilization of soil $N_{\min }$ in the plant biomass.

Large amounts of nitrous oxide emissions observed during DWT with several cycles of soil drying and wetting. Both prolonged drying and prolonged wetting periods decreased the emission. A first peak of $\mathrm{N}_{2} \mathrm{O}$ emission of $27 \mu \mathrm{g} \mathrm{N} \mathrm{m}-2 \mathrm{~h}^{-1}$ was observed at $63 \%$ FC soil moisture in the bare fallow treatment. This peak was related with the maximum of $\mathrm{NO}_{3}-\mathrm{N}$ in the soil and was possibly associated with the oxidation of $\mathrm{NH}_{4}-\mathrm{N}$ (nitrification). In an incubation study, Hütsch et al. (1999) observed a significantly higher amount of emission by changing the soil water content from $60 \%$ to $120 \%$ FC. Flessa et al. (1996) and Bollmann and Conrad (1998) determined nitrification as the main determining process for $\mathrm{N}_{2} \mathrm{O}$ emission in soil with $<80 \%$ FC. Parton et al. (1996) observed the best condition for nitrifiers at $60 \%$ FC soil moisture with large associated $\mathrm{N}_{2} \mathrm{O}$ emissions. By alternate draining and flooding in rice fields, Xing and Zhu (1997) observed 4 times higher $\mathrm{N}_{2} \mathrm{O}$ emission than with continuous flooding in southern China. Kaiser and Ruser (2000) observed inverse relation between $\mathrm{N}$ losses in the form of $\mathrm{N}_{2} \mathrm{O}$ and efficiency of $\mathrm{N}$ uptake by grown crop. The present study, the initial peak of $\mathrm{N}_{2} \mathrm{O}$ emissions at $75 \%$ FC soil moisture could be due to nitrification.

After the onset of monsoon, the soil got saturated and the highest amount of $\mathrm{N}_{2} \mathrm{O}$ emission of $48 \mu \mathrm{g} \mathrm{N} \mathrm{m}{ }^{-2} \mathrm{~h}^{-1}$ was observed in the bare fallow treatment with rapid reduction in the $\mathrm{NO}_{3}-\mathrm{N}$ content in the soil. As $\mathrm{NO}_{3}-\mathrm{N}$ is negatively charged and not sorbed onto clay particles, it is prone to losses, particularly by leaching in sandy soils but also by denitrification, particularly in saturated clay soils (Bacon et al., 1986; Davidson et al., 1986). The second highest peak of $\mathrm{N}_{2} \mathrm{O}$ emissions observed after soil flooding could be due to denitrification in the bare fallow control. The significantly reduced $\mathrm{N}_{2} \mathrm{O}$ emissions from the plots of maize, mucuna and mungbean DWT treatments could be linked with the efficient utilization of Nmin by the crops in plant biomass.

\section{Nitrogen assimilation by transition season crops}

Crops grown during DWT showed large differences in $\mathrm{N}$ accumulation. Total $\mathrm{N}$ accumulation by maize was $43 \mathrm{~kg} \mathrm{~N} \mathrm{ha}^{-1}$ and that of the grain legume mungbean and the green manure legume mucuna were 53 and $80 \mathrm{~kg} \mathrm{~N}$ ha $^{-1}$ respectively in 2001 . Nitrogen-15 analysis indicated that the major portion of this $\mathrm{N}$ was derived from biological nitrogen fixation. The total $\mathrm{N}$ accumulation by mucuna, mungbean and maize were 108,80 and $54 \mathrm{~kg} \mathrm{ha}^{-1}$, respectively in 2003 also and the highest $N\left(116 \mathrm{~kg} \mathrm{ha}^{-1}\right)$ accumulation was from the straw amended mucuna treatment. The $\mathrm{N}$ accumulation by maize was linked to the soil $\mathrm{NO}_{3}-\mathrm{N}$ depletion, however, mungbean and mucuna derived $\mathrm{N}$ from both soil $\mathrm{Nmin}$ and from the atmosphere. The highest amount of above ground biomass was observed with mucuna and growing mucuna during DWT may be a promising option to recycle soil $\mathrm{NO}_{3}-\mathrm{N}$, which may otherwise be loosed, and to add substantial amounts of atmospheric $\mathrm{N}$.

\section{Soil N dynamics during rice growing (wet) period}

The biomass of the crops grown during DWT was incorporated into the soil and observed large differences in soil $\mathrm{NH}_{4}-\mathrm{N}$ among DWT pre-treatments in flooded soil. The highest amount $(51.2$ $\mathrm{kg} \mathrm{ha}^{-1}$ ) of $\mathrm{NH}_{4}-\mathrm{N}$ occurred in the mucuna pre-treatment where $116 \mathrm{~kg} \mathrm{ha}^{-1}$ biomass $\mathrm{N}$ was recycled. Second higher amount $\left(49 \mathrm{~kg} \mathrm{ha}^{-1}\right)$ of $\mathrm{NH}_{4}-\mathrm{N}$ was observed in mungbean treatment, and the lowest soil $\mathrm{NH}_{4}-\mathrm{N}\left(22 \mathrm{~kg} \mathrm{ha}^{-1}\right)$ was observed in the bare fallow treatment during the 
initial two weeks after soil flooding and it rapidly declined afterwards. There was sharp decline in the soil $\mathrm{NH}_{4}-\mathrm{N}$ content 4 weeks after rice transplanting in all treatments and that was possibly associated with $\mathrm{N}$ uptake by the growing rice crop.

Rice grain yield and $\mathrm{N}$ uptake

Rice grain yield responded to the $\mathrm{N}$ savings and/or $\mathrm{N}$ adding effects (BNF) of the DWT pretreatments. The lowest rice grain yield of $1.7 \mathrm{Mg} \mathrm{ha}^{-1}$ (average of 2001 and 2003) was obtained from the DWT period bare fallow treatment. The wet season rice grain yield of 2.5, 2.9 and $3.7 \mathrm{Mg} \mathrm{ha}^{-1}$ (average of 2001 and 2003), were observed in the DWT pre-treatments maize, mungbean and mucuna respectively. The highest grain yields of $3.61 \mathrm{Mg} \mathrm{ha}^{-1}$ in 2001 and of $3.79 \mathrm{Mg} \mathrm{ha}^{-1}$ in 2003 were observed in the mucuna treatment with $\mathrm{N}$ uptake of $77 \mathrm{~kg}$ ha-1. The lowest $\mathrm{N}$ uptake of $32 \mathrm{~kg}$ ha-1 was determined in the bare fallow pre-treatment. The highest $\mathrm{N}$ uptake determined in the mucuna pre-treatment could be associated with combined effects of soil $\mathrm{N}$ savings and atmospheric $\mathrm{N}_{2}$ fixation.

Grain yield is related to the amount of available $\mathrm{N}$ in the soil pool and to the $\mathrm{N}$ uptake capacity of the crop (Cassman et al., 1997). Becker et al. (1990), Ladha and Reddy (2003) showed increased grain yield of the subsequent rice crop by growing legumes and recycling their biomass in the field. Peoples et al. (1995) reported upto $120 \mathrm{~kg} \mathrm{ha}-1$ of the nitrogen fertilizer equivalence (NFE) for green manures and grain legume residues. Becker and Ladha, (1996) showed high synchrony among $\mathrm{N}$ supply of incorporated legume residue, $\mathrm{N}$ demand and $\mathrm{N}$ recovery by rice. In present study also, the highest grain yield in the mucuna pre-treatment could be linked with synchronization among residue mineralization, $\mathrm{N}$ demand and $\mathrm{N}$ uptake by rice plant. Similarly, the lowest grain yield in the bare fallow pre-treatment could be the result of heavy $\mathrm{N}$ loss during DWT period by both leaching and denitrification.

\section{CONCLUSION}

Massive loss of native soil nitrogen occurs in rice-wheat rotations when fields are left bare fallow during the dry-to-wet season transition period. Growing grainlegumes and green manure crops during the transition season can immobilize soil $\mathrm{N}$ in the plant biomass in addition to adding $\mathrm{N}$ from the atmosphere. Reduced amounts of available soil Nmin by growing crops during DWT result reduced $\mathrm{N}$ losses by both leaching and denitrification. That also reduces $\mathrm{N}_{2} \mathrm{O}$ emission from the soil and increases grain yields of subsequent crop rice substantially. While these management strategies can effectively enhance $\mathrm{N}$ cycling in ricewheat rotation system but $\mathrm{N}$ balance indicates that in the long term, crop yields cannot be sustained without the additional application of mineral fertilizers and/or compost. The combination of the proposed options with the application of other organic manures (compost) and chemical fertilizers can sustain the system with increased grain yield of rice.

\section{REFERENCES}

Bacon, P.E., J.W. Mc Garity, E. H. Hoult and D. Alter, 1986. Soil mineral nitrogen concentration within cycles of flood irrigation: Effect of rice stubble and fertilization management. Soil Biol. Biochem, 18:173-178.

Becker, M. and J.K. Ladha, 1996. Synchronizing residue Nmineralizationwith rice $\mathrm{N}$ demand in flooded conditions. In: K. Giller and G. Cadisch (eds.). Driven by nature: Plant litter quality and decomposition. CAB International, London, pp231-238. 
Becker, M., J.K. Ladha and J.C.G. Ottow, 1990. Growth and nitrogen fixation of two stem- nodulating legumes and their effect as green manure on lowland rice. Soil Biol. Biochem, 22:1109-1119.

Bollmann, A. and R. Conrad, 1998. Influence of $\mathrm{O} 2$ availability on $\mathrm{NO}$ and $\mathrm{N}_{2} \mathrm{O}$ release by nitrification and denitrification in soils. Global Change Biology, 4:387-396.

Cassman K.G., D.C. Olk and A. Dobermann, 1997. Scientific evidence of yield and productivity declines in irrigated rice systems of tropical and subtropical Asia. FAO Int. Rice Comm. Newsl, 46:7-18.

CBS, 2001. Statistical pocket book of Nepal. Central Bureau of Statistics (CBS), His Majesty's Government of Nepal, Kathmandu, Nepal.

Davidson, E. A., W. T. Swank and T. O. Perry, 1986. Distinguising between nitrification and denitrification as sources of gaseous nitrogen production in soil. Appl. Environ. Microbiol, 52:12801286.

Flessa, H., W. Pfau, P. Dörsch and F. Beese, 1996. The influence of nitrate and ammonium fertilization on $\mathrm{N}_{2} \mathrm{O}$ release and $\mathrm{CH}_{4}$ uptake of a well drained topsoil demonstrated by a soil microcosm experiment. Z. Pflanzenernähr. Bodenkd, 159:499-503.

Gami, S. K., J. K. Ladha, H. Pathak, M. P. Shah, E. Pasuquin, S.P. Pandey, P.R. Hobbs, D. Joshi and R. Mishra, 2001. Long-term changes in yield and soil fertility in a twenty-year rice-wheat experiment in Nepal. Biol. Fertil. Soils, 34:73-78.

Harrington, L.W., S. Fujisaka, P.R. Hobbs, C. Adhikari, G.S. Giri and K. Kassaday, 1993. Rice-wheat cropping systems in Rupandehi district of Nepal Terai: Diagnostic surveys of farmers practices and problems and needs for further research. NARC/CIMMYT/IRRI Mimeograph. Mexico D.F.

Hartemink, A.E., R.J. Buresh, B. Jama and B.H. Janssen, 1996. Soil nitrate and water dynamics in sesbania fallows, weed fallows and maize. Soil Sci. Soc. Am. J., 60:568-574.

Hobbs, P. R. and M. Morris, 1996. Meeting South Asia's future food requirements from rice-wheat cropping systems: Priority issues facing researchers in the post green revolution era. NRG paper 9601. CIMMYT, Mexico.

Hobbs, P.R. and B. Adhikari, 1997. The importance of rice-wheat systems for food security in Nepal. In: Proceeding of a DFID end-of-project workshop, 1-3 October 1997, CIMMYT Mexico DF, pp1-5.

Hütsch, B.W., X. Wang, K. Feng, F. Yan and S. Schubert, 1999. Nitrous oxide emission as affected by changes in soil water content and nitrogen fertilization. J. Plant Nutr. Soil Sci., 162:607-613.

Inubushi, K., H. Naganuma and S. Kitahara, 1996. Contributions of denitrification and autotrophic and heterotrophic nitrification to nitrous oxide production in Andosols. Biol. Fertil. Soils, 23:292-298.

Kaiser, E.A. and R. Ruser, 2000. Nitrous oxide emissions from arable soils in Germany- an evaluation of six long-term field experiments. J. Plant Nutr. Soil Sci., 163:249-260.

Kladivko, E.J., J.R. Frankenberger, D.W. Jaynes, B.J. Jekinson and N.R. Fausey, 2004. Nitrate leaching to subsurface drains as affected by drain spacing and changes in crop production system. J. Environ. Qual., 33:1803-1813.

Ladha, J. K., K.S. Fischer, M. Hossain, P.R. Hobbs and B. Hardy, 2000. Improving the productivity and sustainability of rice-wheat systems of the Indo-Gangetic plains: A synthesis of NARS-IRRI partnership research. International Rice Research Institute, Makati City, Philippines, pp1-31.

Ladha, J.K. and P.M. Reddy, 2003. Nitrogen fixation in rice systems: State of knowledge and future prospects. Plant Soil, 252:151-167.

Pande, K.R. and M. Becker, 2003. Seasonal soil nitrogen dynamics in rice-wheat cropping systems of Nepal. J. Plant Nutr. Soil Sci., 166:499-506.

Pandey, P.R., S.P. Pandey and Y.G. Khadka, 1999. Long-term effect of organic and indorganic fertilizer on rice-wheat system in rainfed lowland condition of Khumaltar. In: Maskey, S.L et al., (eds.), Proceedings of first national workshop on long term soil fertility experiments, 11-13 Aug. 1999, Soil Science Division/ Nepal Agricultural Research Council, Nepal, pp116-134. 
Parton, W.J., A.R. Mosier, D.S. Ojima, D.W. Valentine, D.S. Schimel, K. Weier and A.E. Kumala, 1996. Generalized model for $\mathrm{N}_{2}$ and $\mathrm{N}_{2} \mathrm{O}$ production from nitrification and denitrification. Global Biogeochem. Cycles, 10:401-412.

Peoples, M.B., D.F. Herridge and J.K. Ladha, 1995. Biological nitrogen fixation: an efficient source of nitrogen for sustainable agricultural production? Plant Soil, 174:3-28.

Regmi, A. P., J. K. Ladha, H. Pathak, H.E. Pashuquin, C. Bueno, D. Dawe, P.R. Hobbs, D. Joshy, S.L. Maskey and S.P. Pandey, 2002. Yield and soil fertility trends in a 20-year rice-rice-wheat experiment in Nepal. Soil Sci. Soc. Am. J., 66:857-867.

Sehy, U., J. Dieckmans, R. Ruser and J.C. Munch, 2004. Adding dissolved organic carbon to stimulate freeze/thaw related $\mathrm{N}_{2} \mathrm{O}$ emissions from soil. J. Plant Nutr. Soil Sci., 167:471-478.

Shrestha, R. K. and J.K. Ladha, 1998. Nitrate in groundwater and integration of nitrogen-catch crop in rice-sweet pepper cropping system. Soil Sci. Soc. Am. J., 62:1610-1619.

Xing, G.X and Z.L. Zhu, 1997. Preliminary studies on $\mathrm{N}_{2} \mathrm{O}$ emissions from three rice paddy fields in China. Nutr. Cycl. Agroecosyst, 49:23-28. 